\title{
Peluang dan Tantangan Program Studi Pendidikan Nonformal dalam Pembangunan Masyarakat Pasca Implementasi UU Nomor 23 Tahun 2014 tentang Pemerintah Daerah di Era Ekonomi Digital
}

\section{Opportunities and Challenges of the Non-Formal Education Study Program in Community Development after the Implementation of Law Number 23 of 2014 concerning Regional Government in the Digital Economy Era}

Muhammad Ivan

Kementerian Koordinator Bidang Pembangunan Manusia dan Kebudayaan

\section{Penulis Korespondensi}

Muhammad Ivan

ivansky5981@gmail.com +6281318438205

\begin{abstract}
Abstrak
UU Nomor 23 Tahun 2014 tentang Pemerintah Daerah membuka ruang Pendidikan Non Formal untuk berperan lebih terkhusus dalam menampung warga yang tidak tuntas mendapatkan pendidikan formal. Di tengah era Revolusi Industri 4.0 telah memicu pergeseran sistem pembangunan SDM baik dalam Pendidikan Formal, Informal, dan Non Formal untuk beradaptasi di era digital. Pengentasan kemiskinan yang menjadi salah satu tujuan Prioritas Nasional dalam Rencana Kerja Pemerintah tahun 2019 mendorong Prodi PNF untuk memiliki sistem pembangunan SDM terkhusus SDM yang tidak terakomodir pendidikan formal, masyarakat kelas pekerja, perempuan, anak putus sekolah, dan etnis minoritas maupun kelas sosial yang terkucilkan. Ekonomi digital menawarkan solusi dengan berbagai spesifikasi pekerjaan baru dan menghilangkan 50 juta peluang kerja dalam beberapa waktu ke depan. Penelitian ini menggunakan pendekatan kualitatif dan menggunakan metode literatur. Hasil penelitian menunjukkan bahwa Prodi PNF berpeluang menjadi wadah pemikir dengan melakukan riset untuk mengidentifikasi kebutuhan masyarakat dan tren ekonomi digital yang terus berkembang. Temuan penelitian bahwasanya Prodi PNF dapat menjadi wadah pemikir untuk menghasilkan riset yang berdaya guna bagi kementerian dan lembaga. Kesimpulan dalam penelitian ini menunjukkan bahwa dalam hal pengentasan kemiskinan peran Prodi PNF sejalan dengan Prioritas Nasional dalam Rencana Kerja Pemerintah yang bertujuan untuk meningkatkan kualitas pembangunan masyarakat.
\end{abstract}

\section{Kata Kunci}

pendidikan nonformal; UU Nomor 23 Tahun 2014; pembangunan masyarakat; pengentasan kemiskinan; ekonomi digital

\begin{abstract}
Law Number 23 of 2014 concerning Regional Government opens up space for Non-Formal Education to play a more specific role in accommodating residents who have not completed formal education. In the midst of the Industrial Revolution 4.0 era, it has triggered a shift in the $H R$ development system both in Formal, Informal, and Non-Formal Education to adapt in the digital era. Poverty alleviation which is one of the National Priority goals in the Government's 2019 Work Plan encourages the PNF Study Program to have a human resource development system,
\end{abstract}


ARTIKEL

especially human resources that is not accommodated by formal education, working class communities, women, out-of-school children, and ethnic minorities and excluded social classes. The digital economy offers solutions with new job specifications and eliminates 50 million job opportunities in the near future. This study uses a qualitative approach and uses the literature method. The results of the study indicate that the PNF Study Program has the opportunity to become a forum for thinking by conducting research to identify the needs of the community and the growing trend of the digital economy. The research findings show that the PNF Study Program can be a think tank to produce useful research for ministries and institutions. The conclusion in this study shows that in terms of poverty alleviation the role of the PNF Study Program is in line with the National Priorities in the Government Work Plan which aims to improve the quality of community development.

\section{Keywords}

non-formal education; Law Number 23 of 2014; community development; poverty alleviation; digital economy 


\section{Pendahuluan}

Era digital menawarkan pendekatan berbeda dalam belajar dan bekerja. McKinsey dan Co baru-baru ini memperkirakan bahwa Indonesia memiliki potensi digital yang belum dimanfaatkan hingga USD150 miliar. Dunia pendidikan sudah seharusnya dapat menangkap sinyal bahwa kepala sekolah dan guru membutuhkan learning capacity untuk beradaptasi dengan era digital yang sangat potensial terkhusus di daerah 3T. Daerah 3T, bukanlah daerah yang selalu miskin. Dengan pengelolaan sumber daya yang baik, daerah $3 \mathrm{~T}$ dapat menjadi muara ekonomi kawasan.

Selalu ada ancaman di setiap perubahan. Namun, perlu dilihat potensi perubahan tersebut bagi masyarakat. Era digital, salah satunya lebih dulu mewabah ke insan muda. Mereka sudah cukup adaptif, begitu mudah mereka mengetikkan jemarinya ke smartphone atau tombol laptop. Adanya ojek dan taksi online membuktikan bahwa tiap perubahan selalu berisiko. Salah satunya, sopir angkot dan ojek pangkalan yang tergusur dan tergerus dengan eksistensi layanan online. Perubahan tersebut berperan vital dalam pembangunan masyarakat. Tentu saja, peran pemerintah perlu memetakan permasalahan pembangunan akibat dari perubahan tersebut.

Berdasarkan data (Dobbs dkk., 2012) Indonesia membutuhkan sekitar 58 juta tenaga kerja terampil untuk menjadikan ekonomi Indonesia peringkat ke-7 pada 2030 mendatang. Kondisi sebaliknya, terjadi 23 persen penurunan penduduk usia kerja di Eropa pada 2010 sampai 2050 akibat ageing society.

Isu pembangunan masyarakat identik dengan perubahan sosial yang secara struktural direncanakan oleh pemerintah dalam rencana pembangunan. Masyarakat seperti apakah yang ingin dihasilkan oleh pemerintah tersebut baik secara implisit maupun eksplisit dalam Rencana Kerja Pemerintah tiap tahunnya. Pembangunan masyarakat atau yang dinamakan Community Development diartikan bahwa perubahan sosial terjadi untuk pembangunan masyarakat dan pembangunan masyarakat mendorong terjadinya perubahan sosial. Apalagi perubahan tersebut berdampak pula pada semakin terpinggirkannya daerah 3T.
Daerah 3T membutuhkan layanan internet yang memadai (Muhammad, 2017). Penelitian McKinsey dan Co (Das dkk., 2016) penetrasi internet di Indonesia masih rendah (34 persen), perjalanan menuju era digital menjadi terhambat terkhusus di daerah 3T. Menurut The Global Competitiveness 2016-2017, Indonesia berada di peringkat ke-91-di mana tingkat pilar kesiapan teknologi (di bawah 6) karena penetrasi internet masih rendah. Hanya satu dari lima orang yang menggunakan internet dan hanya ada satu koneksi broadband tiap 100 penduduk. Namun, teknologi dalam perusahaan lebih tersebar (peringkat 53).

Di sektor informal, melansir The International Labor Organization (ILO), diperkirakan lebih dari 35 juta wanita yang tidak bekerja antara usia 15 dan 64 tahun menunjukkan, bahwa dengan platform online, Indonesia dapat mengaktifkan 3 persen dari populasi ini-menambahkan 1 juta orang untuk tenaga kerja Indonesia. Ini baru dari jalur informal, pekerja rumah tangga, belum lulusan yang telah dibekali kompetensi dalam pasar kerja digital.

Dampak ekonomi sebesar USD 150 miliar per tahun pada 2025 terlalu indah untuk diabaikan (Rantung, 2021). Menerapkan strategi digital yang holistik di ranah pendidikan ikut mendorong bagaimana tenaga kerja Indonesia dapat bersaing dengan tenaga kerja asing. Peran pendidikan non formal akan sangat berperan dalam menunjang masyarakat untuk mencapai berbagai keterampilan yang dibutuhkan di era digital.

Jika kembali pada UU No. 20/2003 tentang Sistem Pendidikan Nasional, pemerintah memang menempatkan pendidikan nonformal atau PNF untuk mengakomodasi keterbatasan pendidikan formal. Sebagai subsistem pendidikan, PNF memiliki peran yang tidak kecil dari pendidikan anak usia dini hingga menyiapkan warga dengan keterampilan baru.

Apa pun istilahnya ketika dunia pendidikan tidak lagi berjalan "normal", saat itulah peran PNF menjadi platform yang tidak dapat diabaikan untuk menopang siswa/warga mengatasi loss learning berkepanjangan yang memiliki multiplier effect pada masa mendatang.

PNF telah menjadi bagian pembicaraan internasional terutama kebijakan tentang pendidikan pada era sebelum tahun 1960 dan akhir tahun 1970-an. Di banyak negara isu PNF menjadi topik-topik khusus yang dianggap 
sebagai pendidikan yang menjadi pemecah bagi persoalan-persoalan layanan pendidikan masyarakat, terutama masyarakat yang tidak terlayani pendidikan formal.

Community Development merupakan konsep pembangunan masyarakat yang telah dikembangkan dan diterapkan sejak dasawarsa 60-an, yaitu dalam rencana pembangunan lima tahun 1956-1960 atau yang dikenal dengan nama Rencana Juanda yang disusun oleh Biro Perancang Negara. Titik berat pembangunan adalah pada pembangunan masyarakat, dengan pembentukan kader-kader pembangunan masyarakat desa yang tangguh yang diharapkan akan menopang tercapainya masyarakat desa yang mampu berswasembada (Zamhariri, 2008).

Pemakaian istilah pembangunan masyarakat (community development) mulai dipergunakan pertama kali secara umum di dunia pembangunan masyarakat sebagai program nasional yang luas dari pemerintahan kolonial Inggris sebagai pengganti istilah "Mass Education” (Pendidikan Masal) yang sebelumnya diberlakukan pada semua negara-negara koloninya pada sekitar tahun 1948 (Gunawan, 2017).

Perkembangan masyarakat mengalami perubahan yang transformasional. Isu perubahan dan perkembangan masyarakat secara teoritis dipelajari dalam sosiologi. Namun isu-isu pembangunan masyarakat yang berada pada applied science bukan lagi berbicara pada keilmuan dan nilai-nilai ilmiah di dalamnya, namun juga membicarakan kaji-aksi yang secara implementatif saling berkolaborasi satu sama lain.

Dinamika teori pembangunan tersebut tidak terlepas dari pemahaman terhadap konsep pembangunan yang bersifat terbuka ujungnya. Pengalaman selama ini menunjukkan bahwa implementasi konsep pembangunan ternyata telah banyak mengubah kondisi kehidupan masyarakat.

Pembangunan masyarakat diartikan sebagai aktivitas yang dilakukan oleh masyarakat, di mana mereka mampu mengidentifikasikan kebutuhan dan masalah secara bersama. Ada pula yang mengartikan bahwa pembangunan masyarakat adalah kegiatan yang terencana untuk menciptakan kondisi-kondisi bagi kemajuan sosial ekonomi masyarakat dengan meningkatkan partisipasi masyarakat (Mahendra, 2013).
Secara historis, pembangunan masyarakat (pedesaan) pada masa yang lalu mendasarkan pada asas pemerataan yang penerapannya diarahkan secara sektoral dan pada setiap desa. Raharjo (2006) dalam Abdiyanto (2015) bahwasanya meskipun dana/ anggaran/ bantuan pembangunan pedesaan jumlahnya relatif cukup besar, tetapi jika dibagi secara merata maka masing-masing desa memperolah jumlah dana yang relatif kecil, sehingga pemanfaatannya kurang berhasil. Dalam konteks Indonesia, Community Development akan mendapat tantangan yang cukup besar karena perubahan dimensi pembangunan yang mulai mengarah ke Revolusi Industri 4.0. Menurut Menristekdikti Mohamad Nasir bahwa perubahan teknologi informasi sangat mendukung perkembangan revolusi industri 4.0, negara yang akan menjadi pemenang bukan negara yang penduduknya besar, tetapi negara yang mempunyai inovasi besar akan menjadi pemenangnya (Ristekdikti, 2018).

Menurut Dirjen Bangdes dalam Zamhariri (2008) pada hakikatnya pembangunan masyarakat merupakan proses dinamis yang berkelanjutan dari masyarakat untuk masyarakat untuk mewujudkan keinginan dan harapan hidup yang lebih sejahtera dengan strategi menghindari kemungkinan tersudutnya masyarakat sebagai pengguna akses dari pembangunan regional/ daerah atau nasional. Pengertian tersebut mengandung makna betapa pentingnya inisiatif lokal, partisipatif masyarakat sebagai bagian dari model-model pembangunan yang dapat menyejahterakan masyarakat desa. Program pembangunan ini tidak berpusat pada birokrasi melainkan berpusat pada masyarakat atau komunitasnya sendiri.

Dalam tatanan ideal pembangunan seharusnya menjadi tanggung jawab bersama antar pemerintah dan rakyat melalui community power-nya, sehingga tidak akan terjadi pengklaiman bahwa pemerintah sebagai penanggung jawab pembangunan. Sentralistik dan uniformalitas yang dibangun oleh rezim orde baru telah menyebabkan lumpuhnya partisipasi dan kreativitas masyarakat bawah yang berpengaruh signifikan pada kesejahteraan masyarakat.

Sebagaimana (Korten, 1987) menjelaskan bahwa pilihan pendekatan pembangunan yang berorientasi pada pertumbuhan ekonomi bukan saja telah 
mengakibatkan berbagai bentuk ketimpangan sosial tetapi juga menimbulkan berbagai persoalan lain seperti timbulnya akumulasi nilai-nilai hedonistik, ketidakpedulian sosial, erosi ikatan kekeluargaan dan kekerabatan, lebih dari itu pendekatan pembangunan tersebut telah menyebabkan ketergantungan masyarakat pada birokrasi-birokrasi sentralistik yang memiliki daya absorpsi sumber daya yang sangat besar, namun tidak memiliki kepekaan terhadap kebutuhan-kebutuhan lokal, dan secara sistematis telah mematikan inisiatif masyarakat lokal untuk memecahkan masalah-masalah yang mereka hadapi. Ini yang terjadi pada kegagalan orde baru yang terlalu top down dalam perencanaan pembangunan di desa.

Hingga tahun 2017, Badan Pusat Statistik (BPS) mencatat ketimpangan pendapatan Indonesia belakangan ini cenderung memburuk. Hal itu ditandai dengan indeks gini yang mendekati 0,5 atau gini ratio pengeluaran pada 2015 sekitar 0,413 dan 2017 sedikit menurun menjadi 0,397 . Sebaliknya, angka kemiskinan pada 2017 meningkat menjadi 27,77 juta orang dari 2016 yang mencapai 27,76 juta.

Kondisi politik melalui data ekonomi Indonesia mencatat, ketika usaha konglomerat Indonesia semakin membesar pada 1996, kesenjangan sosial semakin besar (dengan indeks gini 0,35) hampir sebagian besar konglomerat melarikan uangnya ke luar negeri pada krisis ekonomi 1997/1998. Oleh karenanya, peran pembangunan masyarakat akan sangat penting sebagai bentuk penyadaran dan pencerdasan masyarakat untuk memainkan peran dalam pembangunan yang telah masuk ke revolusi industri 4.0. Revolusi industri 4.0 diartikan sebagai generasi keempat ini ditandai dengan kemunculan superkomputer, robot pintar, kendaraan tanpa pengemudi, editing genetik dan perkembangan neuroteknologi yang memungkinkan manusia untuk lebih mengoptimalkan fungsi otak.

Jika dinamika industri sudah mampu mengubah wajah ekonomi, maka masyarakat pun ikut terpengaruh dalam perubahan. Secara sosiologi, menjadi sebuah catatan bagi program studi Pendidikan Non Formal untuk melihat pendidikan tidak lagi sekadar pendidikan, melainkan pendidikan sebagai hal yang besar dan memerlukan "belicopter view" untuk mengamati apa yang akan terjadi di kemudian hari. Sangat mustahil, jika kader PNF kaku dalam analisa perubahan sosial atau tidak mampu melakukan intervensi baik secara konsep maupun metodologis terhadap masyarakat yang akan diubah perilakunya. Bentuk perubahan perilaku dan penyadaran merupakan akumulasi hasil dari impact keberhasilan nyata kader pendidik nonformal.

Community Development sering dikaitkan dengan persyaratan seperti pengembangan kapasitas masyarakat, vitalitas masyarakat, pemberdayaan, pembangunan pedesaan atau kemandirian. Unsur-unsur dasar tindakan kolektif, kepemilikan dan perbaikan keadaan umum terjadi pada semua gagasan. Mungkin ada sedikit perbedaan dalam penekanan. Misalnya, sementara pengembangan kapasitas masyarakat berfokus pada pengembangan aset dan kemampuan masyarakat, istilah ini pada dasarnya identik dengan pengembangan masyarakat.

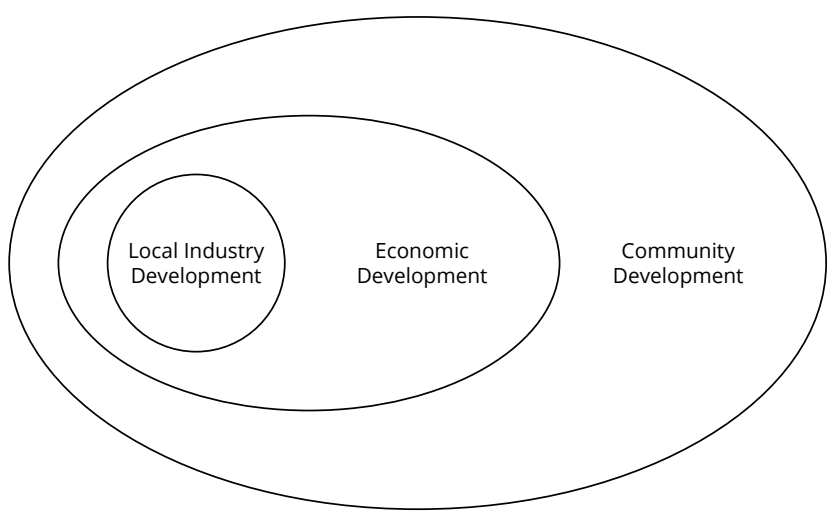

Gambar 1. Hubungan antara Pembangunan Industri, Pengembangan Ekonomi, dan Pembangunan Masyarakat

Pembangunan masyarakat menggabungkan gagasan "komunitas" dengan "pembangunan". Kami telah membahas konsep komunitas sebelumnya- sekelompok orang dengan orang lain identitas. Oleh karena itu, pengembangan masyarakat bergantung pada interaksi antara manusia dan masyarakat aksi bersama, bukan aktivitas individu-yang oleh beberapa sosiolog disebut "agen kolektif" (Flora \& Flora, 1993).

Dapat dijelaskan dalam gambar di atas, bahwa community development menjadi suatu kemutlakan mempengaruhi kondisi economic development dan pembangunan industri lokal di daerah. Community development bukan mengidentifikasi hanya pada isu-isu lokal desa atau wilayah tertentu, namun secara luas, visi 
community development tersebut harus dikaji secara makro, kemudian dipilah kerangka pembangunan ekonomi dan industri lokal. Menjadi logis, bahwa pembangunan ekonomi hanya bagian dari community development. Tentu saja ini menjadi isu menarik di tengah diterapkannya UU Nomor 23 Tahun 2014 tentang Pemerintah Daerah.

UU tersebut menekankan bahwa sektor pendidikan menengah dialihkan ke provinsi, yang memiliki landscape lebih luas dibanding jika hanya diurus oleh Kabupaten/Kota. Perubahan ini pun menggambarkan peran pembangunan masyarakat untuk mengambil atau menciptakan peluang terkhusus di daerah-daerah dengan APK SMA/SMK yang masih rendah. Banyaknya angka putus sekolah dan perkawinan anak dini usia telah melumpuhkan posisi anak sebagai anak muda produktif yang belum dimaksimalkan potensinya. Gubernur Lampung tahun 2017 telah melakukan intervensi langsung dengan mewajibkan anak-anak yang berada pada usia sekolah yang masih ada di jalan pada saat jam belajar sekolah, dimasukkan ke paket A, B, dan C. Untuk skala provinsi, APK rendah menggambarkan ketidakbecusan pemerintah daerah dalam mengelola kualitas pendidikan yang dimulai sejak usia dini hingga pendidikan tinggi.

Perubahan paradigma pembangunan dari pembangunan yang berorientasi pada pertumbuhan ekonomi ke arah model pembangunan alternatif yang lebih menekankan pada partisipasi dan pemberdayaan terhadap masyarakat. Kegiatan pembangunan yang dilaksanakan dapat dilanjutkan dan dikembangkan ke seluruh pelosok daerah untuk seluruh lapisan masyarakat. Pembangunan masyarakat ini pada dasarnya adalah dari, oleh, dan untuk seluruh masyarakat, oleh karena itu pelibatan masyarakat seharusnya diajak untuk menentukan visi (wawasan) pembangunan masa depan yang akan diwujudkan.

Ada empat unsur dasar pembangunan masyarakat menurut Dunham (sebagaimana dikutip Ndraha, 1990), yakni: 1) program berencana, 2) pembangkitan tekad masyarakat untuk menolong dirinya sendiri dan tidak selalu bergantung pada pihak lain., 3) bantuan teknis (dari pihak lain), termasuk personil, peralatan, dan dana, 4) pemanduan berbagai keahlian untuk membantu. 
sebelum dan pasca terbitnya UU Nomor 23 Tahun 2014 tentang Pemerintahan Daerah, dan telaah literatur lebih lanjut.

\section{Hasil dan Pembahasan}

\subsection{Mentalitas dalam Dunia Pendidikan}

Angka pengangguran Indonesia sampai Agustus 2017 naik 10.000 orang menjadi 7,04 juta orang dibandingkan dengan Agustus 2016 yang sebanyak 7,03 juta (Julianto, 2017). Jumlah pengangguran jika dilihat dari indikator pendidikan didominasi lulusan Sekolah Menengah Kejuruan (SMK).

Secara statistik, untuk SMK paling tinggi di antara tingkat pendidikan lain yaitu sebesar 11,41\%Sedangkan untuk pendidikan lainnya seperti Sekolah Dasar (SD) sebesar 2,62\%, Sekolah Menengah Pertama (SMP) sebesar 5,54\%, Sekolah Menengah Atas (SMA) sebesar $8,29 \%$, Diploma I/II/III sebesar 6,88\%, dan universitas sebesar 5,18\%.

Terbukanya akses tenaga kerja asing setelah diberlakukannya MEA yang menimbulkan persaingan dengan tenaga lokal. Sedangkan lapangan kerja di Indonesia masih terbatas sehingga menyebabkan tingkat pengangguran masih relatif tinggi . Angka pengangguran 7,04 juta orang (Julianto, 2017). Masih rendahnya kualitas tenaga kerja dibanding kebutuhan industri. Kualifikasi pendidikan dan kompetensi tenaga kerja rendah. BPS tahun 2017 menunjukkan bahwa tingkat pendidikan pekerja di Indonesia sekitar 60\% didominasi oleh pekerja berpendidikan SMP ke bawah dan sekitar $28 \%$ oleh pekerja berpendidikan menengah dan jumlah Lulusan Perguruan Tinggi sekitar 12\%.

Dalam psikologi belajar bahwa kemampuan belajar atau kapasitas belajar siswa tidak didukung lingkungan belajar yang kondusif. Belajar dikondisikan hanya "belajar" untuk "lulus", bukan belajar untuk menimbulkan kesadaran dan mengubah perilaku. Belajar hanya berhenti pada tahap kognisi. Kondisi ini sudah mendarah daging dalam dunia pendidikan. Ijazah menjadi sebuah prasyarat agar siswa mampu menjadikan sertifikat ijazah tersebut untuk mencari pekerjaan. Beberapa hal yang tidak diperhatikan oleh guru dan sekolah serta masyarakat, bagaimana siswa di zaman digital, yang dihuni mayoritas generasi milenial dan generasi $Z$, mulai mengubah arah belajar menjadi bukan sebuah kebutuhan utama, melainkan sesuatu yang terpaksa, bukan demi memperoleh hal-hal substansial untuk memperbaiki kondisi dan kualitas hidupnya.

Dalam teori belajar kognitif (Nurjan, 2016), peran guru menurut teori ini adalah bagaimana dapat mengembangkan potensi kognitif yang ada pada setiap peserta didik. Jika potensi kognitif yang ada pada setiap peserta didik telah dapat berfungsi dan menjadi aktual oleh proses pendidikan di sekolah, maka peserta didik akan mengetahui dan memahami serta menguasai materi pelajaran yang dipelajari di sekolah melalui proses belajar mengajar di kelas.

\subsection{Peran PNF dalam Pengentasan Kemiskinan}

Perlu diketahui bahwa pembangunan masyarakat harus dipahami sebagai sebuah scope yang sangat berkaitan dengan pembangunan ekonomi dan penguatan industri lokal di daerah. Dengan pemahaman ini, maka dalam hal ini, pembangunan masyarakat harus dilihat sebagai muara dari maju mundurnya daerah. Semakin terbangun kualitas masyarakat, maka akan linier dengan kemajuan ekonomi pada masyarakat tersebut.

Kemiskinan yang membelenggu memang tidak secara langsung dapat dijawab sektor pendidikan, namun ranah pembangunan masyarakat yang menjadi ranah dari laboratorium Pendidikan Non Formal (PNF) yang sebelumnya bernama Pendidikan Luar Sekolah (PLS) sesuai dengan UU No. 20 Sisdiknas Tahun 2003. Dinyatakan bahwa Undang-undang No. 20 Tahun 2003 tentang Sistem Pendidikan Nasional:

a. Pasal 13 ayat 1 jalur pendidikan terdiri atas pendidikan formal, non formal dan informal yang dapat saling melengkapi dan memperkaya.

b. Pasal 26 ayat 3 pendidikan non formal meliputi pendidikan kecakapan hidup, pendidikan anak usia dini, pendidikan keaksaraan, pendidikan keterampilan dan pelatihan kerja, pendidikan kesetaraan, serta pendidikan lain yang ditujukan untuk mengembangkan kemampuan peserta didik.

c. Pasal 26 ayat 4 kesatuan pendidikan non formal terdiri atas lembaga kursus, lembaga pelatihan, kelompok belajar, pusat kegiatan belajar masyarakat dan majelis taklim serta satuan pendidikan yang sejenis. 
d. Pasal 28 ayat 4 pendidikan anak usia dini pada jalur pendidikan non formal berbentuk Kelompok Bermain (KB), Taman Penitipan Anak (TPA) atau bentuk lain yang sederajat.

Laboratorium PNF yang memiliki domain kaji-aksi masyarakat yang berada di perguruan tinggi memiliki peran vital untuk menyinergikan dan mengakomodir hal-hal yang tidak diajarkan dalam pendidikan formal. Oleh karenanya, pekerjaan-pekerjaan yang membutuhkan skill baru, harus menjadi fokus perguruan tinggi untuk mengamati tren kebutuhan masyarakat terhadap pekerjaan-pekerjaan tertentu di era digital yang berbeda jauh dari era sebelumnya.

Program studi Pendidikan Non Formal di berbagai daerah perlu mengamati ataupun melakukan analisis terhadap tantangan yang jauh berbeda dari sebelumnya. Sinergi dan bermitra dengan sebanyak-banyaknya lembaga baik dalam maupun luar negeri, menjadi daya dukung untuk mengakselerasi kebutuhan masyarakat sedini mungkin. Secara makro, prodi PNF perlu memperhatikan perkembangan TIK sebagai daya ungkit untuk menghasilkan lulusan-lulusan pemberdaya masyarakat yang tidak atau belum terakomodir maupun menyempurnakan (komplemen, substitusi, maupun suplemen) pendidikan yang "menghasilkan" untuk menambah nilai lebih atau nilai guna. Jika prodi PNF akan menguatkan sisi peningkatan ekonomi masyarakat, maka sebagai institusi akademik, prodi PNF perlu tanggap untuk mengafiliasi pelbagai kebutuhan apa yang dibutuhkan dunia usaha dan dunia industri yang sedang dan akan berkembang di masa mendatang.

Sebagaimana perkembangan teknologi digital yang berdampak disruptif. Studi yang dilakukan McKinsey (Manyika dkk., 2017) bahwa economic disruption atau disrupsi ekonomi diperkirakan akan membawa dampak berupa hilangnya sekitar 45 juta hingga 50 juta peluang kerja di Indonesia dalam beberapa waktu ke depan. Dalam hal ini, orang-orang yang bekerja pada sektor yang tergantikan oleh teknologi akan menjadi kelompok yang sangat rentan.

Sebagaimana diketahui bahwa Lovett pada tahun 1994 menjelaskan bahwa pada awalnya PNF telah dipopulerkan dalam kaitannya dengan negara-negara miskin. Namun, istilah tersebut juga diterapkan pada negara-negara industri, terutama dalam konteks kerja sama dengan kelompok-kelompok yang telah dirugikan dalam hal peluang ekonomi, sosial dan pendidikan, (termasuk masyarakat kelas pekerja, kelompok pengangguran dan perempuan dan etnis minoritas yang telah menderita diskriminasi) sebagai bagian dari strategi memerangi kemiskinan, perampasan dan pengucilan sosial. Sebagaimana dikutip Infed.org (Lovett, 1994) menunjukkan bahwa model pendidikan masyarakat yang berbeda dapat ditempatkan dalam kaitannya dengan organisasi masyarakat, pengembangan masyarakat, tindakan masyarakat, tindakan budaya dan aksi sosial. Pendekatan ini didasarkan pada teori persaingan dan asumsi yang berbeda mengenai penyebab kemiskinan dan pengucilan sosial, dan melibatkan implikasi yang berbeda untuk peran pendidikan dan pembangunan masyarakat dalam pengentasan kemiskinan.

Dalam kebijakan pemerintah melalui Rencana Kerja Pemerintah (RKP) tahun 2019, tujuan pembahasan program daerah yang mendukung Prioritas Nasional bertujuan memperluas sinkronisasi dan harmonisasi perencanaan antar bidang dan antar wilayah baik melalui anggaran dalam DAK Fisik maupun anggaran Kementerian/Lembaga (K/L). Dalam urusan dana desa, perencanaan kegiatan harus direncanakan di tingkat kabupaten/kota, agar desa dan kabupaten selaras perencanaannya. Kegiatan yang masuk Prioritas Nasional lebih diutamakan karena berdampak pada pengurangan kemiskinan, peningkatan pendapatan, dan perluasan aktivitas padat karya tunai.

Sejalan dengan tema RKP 2019 adalah "Pemerataan Pembangunan untuk Pertumbuhan Berkualitas". Pembangunan manusia melalui pengurangan kemiskinan dan peningkatan pelayanan dasar menjadi salah satu prioritas yang dibahas dalam pertemuan Rakortek ini.

Dengan mengikuti track kebijakan pemerintah, maka Program Studi PNF dapat mengambil peran sebagai salah satu lembaga dengan berbagai pemikiran dan riset, program-program intervensi sosial baik sebagai pendamping maupun tutor, dan atau sebagai perencana program yang berafiliasi dengan berbagai $\mathrm{K} / \mathrm{L}$ atau pemerintah daerah yang memiliki program pengurangan kemiskinan. 


\subsection{Transformasi Pembangunan Masyarakat melalui Pendidikan Non Formal}

Implementasi UU 23 Tahun 2014 tentang Pemerintah Daerah membawa dampak signifikan pada beberapa sektor kehidupan. Namun khusus bidang pendidikan, UU ini memberi dampak secara tidak langsung bukan pada pembangunan ekonomi, melainkan pembangunan manusia. Dengan pengalihan kewenangan pendidikan menengah dari kabupaten/kota ke provinsi, maka urusan SMA/SMK baik distribusi guru, mutasi guru, dan pelbagai masalah pendidikan antar kabupaten/kota dapat diminimalisir. Kewenangan provinsi akan memberi fokus yang lebih baik bagaimana meningkatkan pembangunan SDM di jenjang pendidikan menengah.

Dari segi kebijakan, UU 23 Tahun 2014 diperkuat dengan dukungan Peraturan Pemerintah Nomor 2 Tahun 2018 tentang Standar Pelayanan Minimal yang mengakomodir pendidikan menengah, pendidikan khusus, (provinsi), pendidikan anak usia dini, pendidikan dasar, dan pendidikan kesetaraan (kabupaten/kota). Pasal 15 ayat 3 menyatakan bahwa dalam pelaksanaan pemenuhan Pelayanan Dasar sebagaimana dimaksud pada ayat (2), Pemerintah Daerah dapat: a. membebaskan biaya untuk memenuhi kebutuhan dasar bagi Warga Negara yang berhak memperoleh Pelayanan Dasar secara minimal, dengan memprioritaskan bagi masyarakat miskin atau tidak mampu sesuai dengan ketentuan peraturan perundangundangan. Yang dimaksud dengan "membebaskan biaya" antara lain memberikan beasiswa, memberikan barang dan/jasa secara gratis dalam penerapan SPM.

Dalam konteks yang demikian, maka pendidikan formal akan mendapat porsi yang akurat dan hak warga negara memperoleh pendidikan dilindungi dengan adanya PP SPM. Dijelaskan bahwa sejak berlakunya Undang-Undang Nomor 23 Tahun 2014 tentang Pemerintahan Daerah maka SPM tidak lagi dimaknai dalam kontekstual sebagai norma, standar, prosedur, dan kriteria. Batasan pengertian SPM secara tekstual memang tidak berubah, yaitu bahwa SPM merupakan ketentuan mengenai Jenis Pelayanan Dasar dan Mutu Pelayanan Dasar yang berhak diperoleh setiap Warga Negara secara minimal, namun terdapat perubahan mendasar dalam pengaturan mengenai Jenis Pelayanan Dasar dan Mutu
Pelayanan Dasar, kriteria penetapan SPM, dan mekanisme penerapan SPM.

Dengan kondisi ini, prodi PNF harus mengubah mindset bahwa perubahan sosial budaya telah membawa masyarakat pada dunia yang serba instan. Prodi PNF harus berubah dan berhenti hanya untuk cukup bertahan, namun perlu intelektual maupun akademisi PNF berbenah diri melihat bahwa begitu banyak peluang dapat diciptakan dengan meredefinisi PNF. Salah satunya adalah berhenti menganggap bahwa program PNF hanya pada kursus, kesetaraan, dan pelatihan. Masa buta aksara sudah lewat, dan berganti dengan literasi media/sosial media. Pelbagai perubahan masyarakat tidak lagi cukup hanya melalui intervensi sosial, namun intervensi sosial media yang menekankan pentingnya mendekatkan prodi PNF pada kemitraan digital yang saling mempengaruhi.

Berdasarkan data Dobbs dkk. (2012) Indonesia membutuhkan sekitar 58 juta tenaga kerja terampil untuk menjadikan ekonomi Indonesia peringkat ke-7 pada 2030 mendatang. Kondisi sebaliknya, terjadi 23 persen penurunan penduduk usia kerja di Eropa pada 2010 sampai 2050 akibat ageing society.

Australia bahkan menerbitkan buku THE VET ERA: Equipping Australia's workforce for the future digital economy (Schmidt \& Mason, 2016) sebagai penanda bahwa ekonomi digital merupakan pasar potensial bagi tenaga kerjanya untuk mempersiapkan diri sedini mungkin. Indonesia, jangan sampai hanya menjadi konsumen dan penonton di negeri sendiri.

Prodi PNF sebagaimana dijelaskan sebelumnya memiliki peran yang sangat signifikan dalam pengentasan kemiskinan. Dengan berbagai keragaman daerah sasaran, di kota maupun desa, riset makro perlu dilakukan untuk melakukan identifikasi kebutuhan masyarakat.

Secara radikal, PNF dapat menjadi tulang punggung keterbatasan pemerintah dalam mengakomodir pendidikan formal di wilayah rentan baik di tingkatan kabupaten/kota. Kehadiran PNF dapat mengurangi beban masyarakat dengan peningkatan kapasitas belajar dan akselerasi pengetahuan dan keterampilan yang dapat meningkatkan pendapatan. 
Brodjonegoro (2018) mengutip tulisan Schwab yang mengidentifikasi jenis pekerjaan yang akan segera hilang antara lain pemasaran jarak jauh, staf perpajakan, wasithakim garis-petugas olahraga lainnya, sekretaris bidang hukum, perantara tanah-bangunan, kontraktor buruh tani, dan kurir.

Sebaliknya, ada beberapa profesi yang tidak tergantikan fungsinya oleh teknologi mutakhir antara lain pekerja sosial yang menangani orang yang mengalami gangguan kejiwaan atau kekerasan, koreografer, dokter-dokter bedah, psikolog, manajer sumber daya manusia, analis sistem komputer, antropolog-arkeolog, ahli teknik perkapalan, manajer penjualan, dan direktur utama. Hilangnya beberapa jenis pekerjaan berarti terjadi pengurangan peluang kerja. Berkurangnya peluang kerja otomatis akan membuat persaingan untuk memperoleh pekerjaan semakin ketat. Hanya sumber daya manusia yang unggul yang memiliki kompetensi sesuai tuntutan era Revolusi Industri 4.0 yang akan eksis.

Kecakapan di era 4.0 selama ini sudah ada dan tinggal dipacu di Prodi PNF, yakni kemampuan dalam menangani persoalan yang kompleks melalui kecakapan non-rutin dan kecakapan sosial. Kecakapan non-rutin butuh kepekaan karena sasaran masyarakat memiliki kebutuhan belajar yang berbeda-beda. Dalam sistem pembangunan SDM era 4.0, prodi PNF dapat menjadi wadah pemikir dengan melakukan riset pembangunan terkhusus ada bagian dari masyarakat yang tidak tertampung dalam pendidikan formal, seperti anak putus sekolah, lulusan SMK yang masih menganggur, masyarakat kelas pekerja, dan perempuan serta etnis minoritas yang menderita diskriminasi.

Revolusi Industri 4.0 tentu berdampak pula adanya penyimpangan sosial yang dilakukan masyarakat, karena ketidaksiapan dalam beradaptasi dengan situasi baru. Peluang dan tantangan ini menjadikan Prodi PNF akan sangat berperan dalam membangun jembatan antara pemerintah dan institusi lainnya untuk mengangkat kapasitas masyarakat.

\section{Kesimpulan}

Pendidikan Non Formal sangat terkait dengan hubungan antar manusia dan antar kelompok, antar komunitas, atau antar masyarakat yang lebih luas.
Keterbatasan pendidikan formal, memberi peluang cukup luas bagi eksistensi PNF sebagai modalitas pembangunan masyarakat. Investasi pada orang dan pelebaran akses kesempatan belajar sepanjang hayat sama pentingnya sebagai investasi teknologi digital.

Pendidik Non Formal harus memahami bahwa perubahan sosial budaya akan terus terjadi. Namun memastikan bahwa perubahan tersebut bukan terjadi atas alasan teknologi semata, namun bagaimana masyarakat mampu menjadi pengendali dari perubahan tersebut. Jika UU Nomor 23 Tahun 2014 berdampak pada pengalihan kewenangan pendidikan menengah dari kabupaten kota ke provinsi, maka PNF dapat mengambil peluang strategis, yakni a) mendidik mereka yang tidak tertampung di sekolah formal mulai dari usia dini hingga lanjut usia, b) mengidentifikasi tren pekerjaan baru pada ekonomi digital dengan merancang kursus-kursus dan pelatihan baik online maupun offline, c) bermitra dengan berbagai elemen baik pemerintah, swasta, maupun komunitas yang berkaitan dengan ekonomi digital, dan d) sebagai bagian dari pembangunan masyarakat, PNF baik sebagai program studi maupun filosofi pembangunan pendidikan harus senantiasa memunculkan pembaruan-pembaruan dalam pendekatan pendidikan kepada masyarakat menuju masyarakat belajar dan juga masyarakat dengan ekonomi yang lebih baik.

\section{Ucapan Terima Kasih}

Peneliti mengucapkan terima kasih kepada Bapak Wijaya Kusumawardhana sebagai Asisten Deputi PAUD, Dasar, dan Menengah Kemenko PMK atas saran dan bimbingannya selama ini. Kepada Hery Wijayanto dan Dian Vitasari sebagai dukungan kepada penulis hingga terselesaikannya naskah ini.

\section{Referensi}

Abdiyanto. (2015). Pemberdayaan dan Partisipasi Masyarakat dalam Pembangunan Indonesia. Jurnal Mudiraindure.

Das, K., Gryseels, M., Sudhir, P., \& Tan, K. T. (2016). Unlocking Indonesia's Digital Opportunity. In McKinsey \& Company. https:// www.mckinsey.com/featured-insights/asia-pacific/unlockingindonesias-digital-opportunity\#

Dobbs, R., Madgavkar, A., Barton, D., Labaye, E., Manyika, J., Roxburgh, C., Lund, S., \& Madhav, S. (2012). The world at work: Jobs, pay, and skills for 3.5 billion people. In McKinsey Global Institute. https:// www.mckinsey.com/featured-insights/employment-and-growth/ the-world-at-work

Flora, C. B., \& Flora, J. L. (1993). Entrepreneurial Social Infrastructure: A Necessary Ingredient. The ANNALS of the American Academy of Political and Social Science, 529(1), 48-58. https://doi.org/ 10.1177/0002716293529001005 
Gunawan, Y. (2017). Pemberdayaan Masyarakat dalam Pembangunan Desa Tlogoweru [Satya Wacana University Press]. http:// repository.uksw.edu/handle/123456789/13095

Ife, J. W. (1995). Community Development: Creating Community Alternatives: Vision, Analysis, and Practice. Longman Australia.

Julianto, P. A. (2017, November 6). Agustus 2017, Jumlah Pengangguran Naik Menjadi 7,04 Juta Orang. Kompas.com. https:// ekonomi.kompas.com/read/2017/11/06/153940126/agustus-2017jumlah-pengangguran-naik-menjadi-704-juta-orang

Korten, D. C. (1987). Third generation NGO strategies: A key to peoplecentered development. World Development, 15, 145-159. https:// doi.org/10.1016/0305-750X(87)90153-7

Lovett, T. (1994). Radical community education. infed.org: education, community-building and change. https://infed.org/mobi/radicalcommunity-education/

Mahendra, A. (2013). Pendekatan dan Strategi Pembangunan Masyarakat di Indonesia. Multi Sains: Jurnal IImiah Ekonomi, Hukum, Pertanian, Teknik, Kedokteran, Pendidikan, Komputer, 4(4), 32-38.

Manyika, J., Lund, S., Chui, M., Bughin, J., Woetzel, J., Batra, P., Ko, R., \& Sanghvi, S. (2017). Jobs lost, jobs gained: What the future of work will mean for jobs, skills, and wages. In McKinsey Global Institute. https://www.mckinsey.com/featured-insights/future-of-work/jobslost-jobs-gained-what-the-future-of-work-will-mean-for-jobs-skillsand-wages

Muhammad, I. (2017, April 17). Tren dan Tantangan Pendidikan Vokasi di Era Digital. Kumparan.com. https://kumparan.com/ivanmuhammad/tren-dan-tantangan-pendidikan-vokasi-di-eradigital-17uQWi/2

Ndraha. (1990). Budaya Organisasi. PT Rineka Cipta.

Nurjan, S. (2016). Psikologi Belajar. Wade Group.

Rantung, F. (2021, April 23). Ekonomi Digital Indonesia Diprediksi Sumbang USD150 Miliar di $2025 . \quad$ sindonews.com. https:// ekbis.sindonews.com/read/406556/33/ekonomi-digital-indonesiadiprediksi-sumbang-usd150-miliar-di-2025-1619168644

Ristekdikti. (2018). Vol.8.I.2018 1. Ristekdikti, 8(1), 1-56.

Schmidt, J., \& Mason, C. (2016). The VET era: equipping Australia's workforce for the future digital economy. VOCEDplus. http://hdl.voced.edu.au/ $10707 / 408584$

Zamhariri. (2008). Pengembangan Masyarakat: Perspektif Pemberdayaan dan Pembangunan. Komunitas: Jurnal Pengembangan Masyarakat Islam, 4(1), 101-110. 